\title{
W JAKI SPOSÓB MÓWI SIE O KLIMACIE - ANALIZA OSTATNICH TEKSTÓW PRASOWYCH
}

\author{
Marta KWAŚNIEWSKA \\ Doktorantka Uni wersytetu J ana Kochanowskiego w Kielcach, POLSKA \\ DOI 10.25128/2304-1222.19.49.04
}

The paper investigates three press articles concerning the problem of climatechange The texts were extracted from different sources which vary in their political spectrum which may have an impact on the portrayal of the subject. Particular attention is paid to the differences in the presentation of the problem, as well as, the portrayal of peopleand their significance in the context of climate change

Keywords: climate change; press articles; Polish newspapers.

У статті проаналізовано три вибрані статті з преси з різних джерел, які стосуються тематики зміни клімату. Вибрані газети відрізняються ідеологічними профілями, що може впливати на спосіб подання теми. Особлива увага приділяється відмінностям у поданні проблеми, а також позиціонуванні людини в межах проблеми.

Ключові слова: зміни клімату, прес-релізи, польські газети.

Artykuł analizuje trzy wybrane artykuły prasowe pochodzące z różnych źródeł, poruszające temat zmiany klimatu. Wybrane gazety różnią się profilami ideologicznymi, co może mieć wpływ na sposób przedstawienia tematu. Szczególna uwaga jest poświęcona różnicom w prezentacji problemu, a także pozycjonowaniu człowieka w obrębie problemu.

Słowa kluczowe: zriana kimatu, teksty prasowe, gazety polskie.

J ednym z tematów popularnych ostatnio w mediach jest klimat, a konkretniej zmiany jakie w nim zachodzą i ich wpływ na naszą planetę oraz nas samych. Temat jest bardzo kontrowersyjny i istnieje wiele skrajnych opinii na ten temat, pomimo źródeł naukowych o zdecydowanym stanowisku o zmianieklimatu, gl obal nymociepleniui niekorzystnej dla środowiska działalności człowieka (Kundzewicz, 2008). Zanim zostanie omówiony sposób przedstawienia problemu w artykułach prasowych, warto jest zdefiniować omawiane koncepty.

Według Słownika języka polskiego PWN, klimat można zdefiniować jako „charakterystyczny dla danego obszaru zespół zjawisk i procesów atmosferycznych” (,klimat”) lub „nastrój jakiegoś miejsca, środowiska, utworu itp.” (,klimat”). W tym artykule, odnoszę się do pierwszego znaczenia tego pojęcia. Zmianę klimatu natomiast rozważam 
jako znaczącą i długotrwałą zmianę klimatu na Ziemi oraz zmiany w warunkach pogodowych („climate change”). Dodatkowo, ważnym pojęciem pojawiającym się w dyskursie zmiany klimatu, a więc również w omawianych artykułach, jest raport IPCC. IPCC (Intergovernmental Panel on Climate Change), czyli Międzyrządowy Zespół ds. Zmian Klimatu jest to ciało doradcze, o charakterze naukowym i międzyrządowym, z siedzibą w Genewie J ego zadaniemjest, przede wszystkim, zapewnianieobiektywnych oraz naukowych informacji dotyczących zmiany klimatu. Zespół ten, na podstawie badań przeprowadzanych przez naukowców z całego świata, co kilka lat wydaje obszerne raporty na temat zmiany klimatu, traktujące o jej konsekwencjach oraz możliwościach ich ograniCzania Ostatni z tych raportów został opublikowany w 2014 roku. Jednakże, pomiędzy tymi raportami, IPCC publikuje również raporty specjalne, z których ostatni - dotyczący głównie globalnego ocieplenia o 1,5 stopni Celsjusza powyżej poziomów przedindustrialnych, jest omawiany, lub przywoływany w przytoczonych artykułach (IPCC, 2018).

Celem niniejszego artykułu jest analiza wybranych tekstów prasowych dotyczących zmian klimatycznych, w kontekście przedstawienia rzeczonych zmian oraz prezentacji człowieka na ich tle. Materiał badawczy w postaci tekstów prasowych został wybrany z powodu jego powszechności, a także dużym wpływie, jaki może wywierać na odbiorcę. Właśnie z powodu tego wpływu, za ważną uważam analizę artykułów pojawiających się w czasopismach zarówno drukowanych, jak i internetowych.

Jak zauważa Baker (2006 s.72) dziennikarze są w stanie wpływać na czytelnika poprzez produkowanie własnych lub modyfikowanie istniejących dyskursów. Pojedynczy tekst nie jest zazwyczaj znaczący, ale moc mediów tkwi w ich kumulatywności. Wpływ jest wywierany poprzez regularne powtarzanie pewnych treści i postaw. Warto zaznaczyć, że artykuły prasowe mogą wpływać na czytelnika również na inne sposoby, takie jak korzystanie ze starannie dobranych lub wykadrowanych zdjęć, czy posługując się cytatami, często wyrwanymi z kontekstu (Bednarek, 2005).

W celu zbadania jak ostatnio mówi się o klimacie w polskich gazetach, wybrałam po jednym z ostatnich artykułów następujących popularnych polskich gazet: „Polityka”, „Newsweek" oraz „Gazeta Polska”. Gazeta „Polityka” jest tygodnikiem społeczno-politycznym, pod względem ideologicznym prezentujący liberalno-lewicowy profil polityczny. Gazeta „Newsweek Polska” również jest tygodnikiem o charakterze społecznopolitycznym. „Gazeta Polska” jest tygodnikiem ogólnopolskim, koncentrującym się na 
tematyce społeczno-polityczno-historycznej, o profilu prawicowo-konserwatywnym" (Prasa w Polsce).

Należy zaznaczyć, że jest to analiza losowych próbek tekstów prasowych i jako takie należy je traktować. Głębsze i bardziej ilościowe badanie, rozważające możliwe powiązania i trendy pomiędzy prasą o różnych orientacjach politycznych, a także pisane w różnych językach, będzie efektem moich przyszłych badań.

\section{Przedstawienie problemu w gazecie „Polityka”}

W artykule „Rolnictwo i hodowla bydła rujnują naszą planetę. Alarmujący raport IPCC" opublikowanym 8 sierpnia 2009 roku, napisany przez Michała Roleckiego opisuje problem zmiany klimatu z wyraźnym wskazaniem czynnika ludzkiego i stawia człowieka w świetle odpowiedzialności, oczekując od niego działan przeciwdziałających przykrym konsekwencjom. Sytuacja przedstawiona jest jako krytyczna, ale jest również nadzieja. Dobro planety jest przyrównane do ludzkiego bezpieczeństwa.

(1) „Najnowszy raport międzyrządowego panelu do spraw zmian klimatu (IPCC) nie pozostawia złudzeń. Ziemia - tym razem chodzi o gleby, nie planetę ma nas już dosyć."

Główną strategią, mającą wywrzeć wrażenie na czytelniku stosowaną przez autora, jest używanie narracji w pierwszej osobie liczby mnogiej. Kilka przykładów rozważone jest poniżej.

(2) “niszczymy środowisko, zwłaszcza gleby, zbyt szybko, aby mogło nas wyżywić"

(3) "Najwięcej ziem marnujemy na pastwiska (aż 33 proc.). Rolnictwo odpowiada za aż jedną czwartą gazów cieplarnianych uwalnianych do atmosfery."

(4) Powinniśmy zacząć działać już teraz, mówi IPCC. Potrzebujemy mniej pastwisk, a więcej drzew. Jeśli pozwolimy glebom i lasom zregenerować się, zaczniemy jeść mniej mięsa, marnować mniej żywności, będzie mieć to olbrzymi wpływ na naszą planetę i - przez cały łańcuszek powiązań - na nasze bezpieczeństwo.

(5) „Powinniśmy sadzić lasy, gdzie tylko się da, a tymi, które istnieją, gospodarować bardzo rozważnie."

Ten zabieg stylistyczny, nie służy jedynie przedstawieniu człowieka jako osoby odpowieczial nej za konkretny problem, ale może również stanowić istotne narzędzie perswazji. Według Grażyny Habrajskiej (2005, s.112), jest to przejaw budowania relacji JA i TY, nawiązujący kooperację. Jednym ze sposobów jest właśnie utożsamianie się z odbiorcą poprzez używanie zaimków oraz czasowników w pierwszej osoby liczby mnogiej. 
Pomaga to odbiorcy w utożsamianiu się z nadawcą i stanowi zabieg perswazji zewnętrznej.

Liczba mnoga jest używana konsekwentnie w całym artykule, jednak występuje kilka wyjątków, w których można zauważyć większy dystans autora do przedstawionego głównego sprawcy degradacji planety, czyli człowieka.

(6) “Ziemia nigdy przedtem nie wydawała się mniejsza, a jej ekosystemy tak zagrożone. Ludzkość pozostawiła w spokoju tylko nieco ponad ćwierć lądów na Ziemi (28 proc. powierzchni niepokrytej lodem)."

(7) “Czy ludzkość wykaże się rozsądkiem, pokażą dopiero nadchodzące lata."

W podanych wyżej przykładach, pojawia się dystans autora do ludzkości. Nie występuje tu jednocząca liczba mnoga, a ludzie zostają określeni jako jedna masa, bez rozróżnienia jednostkowego.

W niektórych fragmentach natomiast, autor artykułu posiłkuje się bardziej bezosobowymi stwierdzeniami.

(8) "Przepis na katastrofę - degradacja gleb,"

(9) "Mięso wrogiemplanet"

Tutaj autor wskazuje na czynniki doprowadzające do zmian w klimacie, w sposób nie wskazujący bezpośrednio na odpowiedzialne za to osoby, aczkolwiek jest to dopowiedziane dalej w tekście w sposób nie pozostawiający wątpliwości, kto powoduje podane procesy.

Dziennikarz wymienia kilka czynników, które przyczyniają się do tragedii rozgrywającej się na naszej planecie, takie jak hodowla zwierząt na mięso, nierozważne rolnictwo. Należy jednak zwrócić uwagę na to, że za wszystkie z nich bezpośrednio odpowiedzialny jest człowiek. Autor tłumaczy jednak, że sytuacja nie jest beznadziejna.

(10) “IPCC: J eszcze jest nadzieja. Jak się ratować?

W powyższym przykładzie można zauważyć dwie rzeczy, sugerowane przez zaimek zwrotny się. Pierwszą z nich jest to, że zmiana klimatu nie jest destruktywna tylko dla planety, ale także dla ludzi. Po drugie, tylko człowiek ma moc sprawczą by tę sytuację poprawić.

Podsumowując, autor artykułu zdecydowanie umieszcza człowieka jako sedno problemu zmiany klimatu, nie dystansuje się od problemu. Człowiek jest przedstawiony jako główny powód zmian środowiskowych, jako jedna z ofiar tego problemu, ale także jako 
osoba odpowiedzialna i zdolna do poprawy tragicznej sytuacji. Człowiek nie niszczy planety bezpośrednio, ale poprzez nadmierne eksploatowanie jej, poprzez nierozsądne rolnictwo i hodowlę zwierząt oraz nie pozostawienie glebom i lasom czasu na regenerację. Kluczem do walki z klimatem przedstawionym w artykule jest rozsądek ludzkości. Taki obraz zostaje przedstawiony poprzez różnorakie zabiegi perswazyjne, jak na przykład używanie liczby mnogiej czy posługiwanie się przenośniami.

\section{Przedstawienie problemu w gazecie „Newsweek”}

Artykuł prasowy, autorstwa Doroty Romanowskiej, zatytułowany „Skąd się u nas wzięły te zabójcze upały?” został opubl ikowany w gazecie „Newsweek" 15 czerwca 2019 roku. Artykuł ten, opowiada o prądach morskich, zmianach w średnich temperaturach na poziomie globalnym oraz o konsekwencjach tego problemu dla ludzkości. Nie wskazuje on natomiast na przyczynę omawianych zmian, czyli człowieka.

Artykuł można zasadniczo podzielić na wypowiedzi odnoszące się do bezpośrednich przyczyn zmian klimatycznych oraz do tych, mówiących o konsekwencjach powstałego problemu. Najpierw rozważę pierwszą grupę.

(11) „Sprawca tych upałów jest powietrze zwrotnikowe, które napływa do nas z południowego-wschodu."

(12) "Za te fale upałów eksperci winia prąd strumieniowy, czyli wąską strefę silnego wiatru, który wieje na wysokości 9-12 kilometrów, zazwyczaj z prędkością niewiele ponad $100 \mathrm{~km} / \mathrm{h}$, ale może przyspieszyć do 500 .

(13) “Odpowiedzialność za intensywne zmiany prądu strumieniowego spada na Arktykę, która kształtuje klimat na półkuli północnej, a od lat się ociepla."

(14) "Powodem tego miat być zamierajacy Golfsztrom, zwany też Prądem Zatokowym, czyli potężny prąd oceaniczny, który stanowi część cyrkulacji atlantyckiej, odpowiadającej za rozprowadzanie ciepła po oceanie. "

W podanych przykładach autorka tekstu wielokrotnie odnosi się do tzw. sprawców zmian klimatycznych. Wśród nich można odnaleźć powietrze zwrotnikowe, prąd strumieniowy, Arktykę czy Golfsztrom. Zabieg ten, jest przykładem personifikacji. Zjawiskom pogodowym, czy nawet konkretnym obszarom na Ziemi zostają przypisane cechy ludzkie. Poprzez takie zastosowanie środka stylistycznego, zjawiska pogodowe są przedstawionejako odpowiedzial ne za utrzymaniestabilizacji klimatycznej, a wszelkieodchylenia od normy są traktowane jako ich występki wobec prawa i ludzi. 
Zjawisko przypisywania cech ludzkich rzeczom nieożywionym można również zaobserwować, gdy autorka tekstu omawia konsekwencje zmiany klimatu i ich wpływ na człowieka.

(15) „W upalne dni stajemy się poirytowani i agresywni. Nachodzą nas myśli samobójcze"

(16) "Jednak od kilkunastu lat [prąd strumieniowy] zachowuje się bardzo dziwnie Przestał przypominać gładką wstęgę i stał się silnie pofalowany. “

(17) "Arktyka jest bowiem wyjątkowo czuła na wahania temperatur. - J est dla ziemskiego systemu pogodowego niczym kanarek w kopalni, który ostrzegał górników przed toksycznymi gazami"

W przykładzie (16) dziennikarka stosuje pierwszą osobę liczby mnogiej, podobnie jak w przypadku pierwszego omawianego artykułu, podkreślając wspólnotę z czytelnikiem oraz powszechność problemu. W przykładzie (16) autorka zauważa zmianę w wyglądzie prądu strumieniowego, która jest spowodowana zmianą w zachowaniu, ponownie personifikowanego zjawiska. Wreszcie, przykład (17) przyrównuje Arktykę do kopalnianego kanarka, który ma zadanie ostrzegać przed niebezpieczeństwem, najczęściej kosztem własnego życia.

Podsumowując, sposób przedstawienia zmiany klimatu w omawianymartykulesur geruje, że zjawiska pogodowe są odpowiedzialne za stan Ziemi. Wszelkie niekorzystne zmiany są winą tych zjawisk, natomiast rola człowieka w intensywności i występowaniu tychże zjawisk jest nieuwzględniona. Co więcej, w artykule część zjawisk jest personifikowana, można zauważyć użycie liczby mnogiej pierwszej osoby oraz przenośni. To wszystko tworzy obraz świata, w którym człowiek zostaje dotknięty konsekwencjami zmiany klimatu, spowodowanymi niesubordynowanymi zjawiskami pogodowymi.

\section{Przedstawienie problemu w gazecie „G azeta Polska”}

Artykuł zatytułowany „Klimakterium lewactwa. Trzy dekady histerii o ociepleniu”, który został opublikowany 3 lipca 2019 roku w gazecie „Gazeta Polska” jest autorstwa Jacka Lizieniewicza. Całość artykułu ma charakter prześmiewczy, zwłaszcza w stosunku do aktywistów zajmujących się zmianą klimatu. Można również zaobserwować tendencję do bagatelizowania problemu, w sposób perswazyjny.

Pierwszym omawianym tu zabiegiem jest bagatelizacja problemu i uspokajanie czytelnika, powołując się na argumenty mające wskazywać na brak możliwości katastrofy ekologicznej. Poniżej zaprezentowanych jest kilka przykładów. 
(18)“Innym argumentem wskazującym, że katastrofa nam nie groż, jest to, że technologia OZE nie jest transferowana w dużej liczbie do krajów rozwijających się."

(19) “Inną przesłanką na to, że katastrofa nam nie grozi, jest fakt, że ucinane są dyskusje na temat geoinżynierii."

(20) “Na klimat wpływa również aktywność słońca, wiatr kosmiczny, kąt i nachylenie Ziemi, aktywność wulkaniczna i absorpcja dwutlenku węgla przez oceany. [... ] Mimo to 97 proc. kimatologów jest przekonanych, że nasza planeta ociepla się W niespotykanym dotąd tempie i dzieje się to za przyczyną człowieka."

\section{(21) "Ekologicnebrolury opozycji"}

Jak można zauważyć, w podanych przykładach, słowa „katastrofa nam nie grozi” są powtarzane kilkukrotnie, co jest zabiegiem perswazyjnym, często używanym przez dziennikarzy (Baker 2006, s.72) w tym przypadku na mikroskalę, w obrębie jednego artykułu. Co więcej, dziennikarz podważa stanowisko naukowców (20). Wreszcie, w przykładzie (21) można zauważyć sugerowanie braku sensu w ekologicznych postulatach. Wszystkie te zabiegi mają na celu umniejszenie wagi problemu w oczach czytelnika.

Kolejnym zabiegiem, wykorzystywanym w badanym artykule, jest prześmiewcze przedstawienie osób otwarcie walczących ze zmianą klimatu, a także wymienienie konkretnych osób, znanych z mediów, starając się umniejszyć im autorytetu.

(22) "Napędzani temperatura $i$ stońcem aktywiści natychmiast też ruszyli w lud przekonywać, że Ziemia stoi na krawędzi. To już trzecia dekada tej histerii."

(23) "Po raz pierwszy zebrało się ciało mędrców ONZ Międzyrządowy Zespół ds. Zmian Klimatu (IPCC), które doradza rządom w kwestiach zagrożeń klimatycznych. Od tamtej pory upały, huragany, powodzie służą lewicy do wieszczenia końca ludzkości i Ziemi, jaką znamy. No i ciągle koniec świata jest przekładany."

(24) "Bardziej opłaca się więc grać na emocjach i inwestować w propagandę. Po tym, gdy sięgnięto juz po celebrytów pokroju Ala Gora, Arnolda Schwarzeneggera i Leonarda Di Caprio, tym razem moda jest na młodzieńczy bunt. Na jego czele stanęła Szwedka Greta Thunberg, która stała się twarzą młodzieżowych protestów klimatycznych."

W podanych wyżej przykładach, autor artykułu podkreśla, że problem zmiany klimatu jest traktowany nazbyt poważnie, porównując działania podejmowane w celu uświadamiania ludzi o wadze problemu, do obwieszczeń o domniemanych końcach świata, które od czasu do czasu są popularne w mediach. Takie porównanie powoduję utratę wiarygodności przedstawionych postaci, a więc również problemu zmiany klimatu, który reprezentują. Dodatkowo, dziennikarz sugeruje, że osoby związane z działaniem na rzecz walki ze zmianą klimatu, m.in. Al. Gore, Arnold Schwarzenegger czy Leonardo Di Caprio, nie angażują się w sprawę dobrowolnie, a są raczej marionetkami w politycznej 
grze. Zastosowanie wyrażenia „sięgnięto po” w stosunku do ludzi, suponuje użycie metafory.

\section{Ostatnim omawianym tu aspektem przedstawienia problemu zmiany klimatu w artykule}

„Gazety Polskiej”, jest przedstawienie działań jawnie pogarszających stan klimatyczny jako zwycięstwo Polaków, a więc czytelników gazety.

(25) Polska zapłaciłaby co najmniej $870 \mathrm{mld}$ zł za dekarbonizację, którą próbowano przeforsować podczas ostatniego szczytu UE. Skuteczne zablokowanie tych zapędów to wielkie zwycięstwo naszego kraju."

W tym przykładzie można zauważyć zabieg, mający na celu odwrócenie uwagi czytelnika. Dekarbonizacja, a więc sposób na walkę ze zmianą klimatu, jest przedstawiony wyłącznie jako poważny uszczerbek dla Skarbu Państwa. Z drugiej strony, zablokowanie takiego działania jest przedstawione jako sukces ze strony Polski, z którego czytelnik powinien być zadowolony.

Podsumowując, autor omawianego artykułu z „Gazety Polskiej” przedstawia problem zmiany klimatu jako przekoloryzowany i zdecydowanie mniej ważny, niż jest przedstawiany w innych mediach. Stosowane są tu różne zabiegi perswazyjne, na przykład kilkukrotne powtarzanie danych sformułowań, czy wykorzystywanie metafor. Osoby walczące ze zmianą klimatu są ukazane jako rozhisteryzowane i niepotrafiące trzeźwo ocenić sytuacji. Udział ludzi w problemie jest całkowicienegowany.

\section{Podsumowanie}

Reasumując, analiza wybranych artykułów prasowych wykazała, że we wspomnianych artykułach występują trzy różnorakie podejścia do przedstawienia zmian klimatycznych i postawy człowieka wobec nich. W gazecie „Polityka” można zaobserwować otwarte prezentowanie człowieka jako powodu katastrof klimatycznych, ale także jego możliwe działania ku poprawie sytuacji. Zaznaczone jest, że walka ze zmianą klimatu jest w interesie człowieka. Narzędzia perswazji, takie jak używanie liczby mnogiej w pierwszej osobie, czy przenośnie, są użyte w celu utożsamienia człowieka z problem i zachęcenia do działania. W artykule pochodzącym z gazety „Newsweek” mamy do czynienia $\mathrm{z}$ oddzieleniem problemu zmiany klimatu od człowieka, nie wskazywaniem na żadne powiązanie między nimi oraz opisywaniem problemu w sposób neutralny. Przyroda jest tu personifikowana i przedstawiona jako odpowiedzial na za stan naszej planety oraz jako sprawca niekorzystnych zmian. Oprócz personifikacji, stosowana jest również 
liczba mnoga w pierwszej osobie oraz przenośnie. W końcu, „Gazeta Polska” przedstawia problem zmiany klimatu jako przesadzony, bagatelizuje go, wyśmiewa osoby, które aktywnie walczą ze zmianami klimatu oraz ich działania. Rola człowieka w tej zmianie jest natomiast negowana. Podobnie jak w poprzednich artykułach, autor stosuje zabiegi mające na celu przekonanie czytelników do swoich racji, takie jak kilkukrotne powtarzanie poszczególnych wyrażeń czy przenośnie.

Biorąc pod uwagę różnorodne sposoby przedstawiania problemu zmiany klimatu widocznego w omawianych artykułach, można przypuszczać, że mają one odmienny wpływ na swoich czytelników i ich postrzeganie tego problemu. Nie można jednoznacznie stwierdzić, który z artykułów jest najbardziej obiektywny, ponieważ wSzystkiez nich wykorzystują techniki perswazji i wszystkie próbują przekonać czytelnika do swoich racji.

\section{LITERATURA}

Baker, P. Using Corpora in Discourse Anal ysis, London 2006.

Bednarek, M. A. Construing the world: conceptual metaphors and event-construal in news stories, „Metaphorik.de", 2005, 9, 6-32.

Climatechange, in: Merriam-Webster, https://www.merriam-webster.com, [10.07.2019]. Habrajska, G. Nakłanianie, Perswazja, Manipulacja językowa, „Acta Universitatis Lodziensis Folia Litteraria Polonica", 2005, 7, s. 91-126.

IPCC, Global Warming of $1.5^{\circ} \mathrm{C}$. An IPCC Special Report on the impacts of gl obal warming of $1.5^{\circ} \mathrm{C}$ above pre-industrial levels and related global greenhouse gas emission pathways, in the context of strengthening the gl obal response to the threat of climate change, sustai nable devel opment, and efforts to eradi cate poverty, Geneva: World Meteorological Organization, 2018.

Klimat, w: Słownik języka polskiego PWN, URL: https://sjp.pwn.pl, [10.07.2019].

Kunczewicz, Z. W. Konsekwencje global nych zmian kimatu, NAUKA, 2008, 1, 103118.

Lizieniewicz, A. Klimakterium lewactwa. Trzy dekady histerii o ociepleniu, URL: https://www.gazetapol ska.pl/19819-klimakterium-lewactwattzy-dekady-histerio-ociepleniu [16.10.2019].

Prasa w Polsce, w: \#oland, URL: https://web.archive.org/web/20130312090627/http://www.poland.gov.pl/Prasa,w,Polsce,6676.html [21.10.2019].

Rolecki M., Rolnictwo i hodowla bydta rujnuja nasza planete. Alarmujacy raport IPCC, URL: https://www.polityka.pl/tygodni kpolityka/nauka/1918186,1,rol nictwo-i-hodowla-bydl a-rujnuja-nasza-planete-al armujacy-raport-ipcc. read [16.10.2019].

Romanowska D., Skąd się u nas wzięty te zabójcze upaty?, URL: https://www.newswedk.pl/wiecka/nauka/fala-upal ow-w-polsce-skad-sie-urnas-wziely-te-zabojczeupaly/e71jszq, [16.10.2019]. 